\title{
TEKNOLOGI TELEVISI DIGITAL
}

\author{
Nick Soedarso \\ Jurusan Desain Komunikasi Visual, Fakultas Komunikasi dan Multimedia, BINUS University \\ Jln. K.H. Syahdan No. 9, Kemanggisan, Jakarta Barat 11480 \\ nsoedarso@binus.edu
}

\begin{abstract}
Television is the most common medium for people to update the latest information around the world, for more than fifty years. Now, the development of television has grown rapidly to present a picture, even to bring fun to watch movies at home. With HDTV technology, consumers can now enjoy more highly detailed images to be enjoyed with family. This article is based on literature study, on printed and electronic references. The higher the TV resolution does not mean that the picture performance will be better. For HD format, there are 720 vertical lines; meanwhile for full HD there are 1080 vertical lines. TV in low resolution perhaps having good picture quality, but not all the luxury could be enjoyed in details like in HD or full HD format.
\end{abstract}

Keywords: television, monitor, HDTV, resolution

\begin{abstract}
ABSTRAK
Televisi merupakan media yang paling umum untuk manusia memutahirkan informasi terbaru di seluruh dunia, selama lebih dari lima puluh tahun. Sekarang, perkembangan tv sudah kian pesat untuk mempresentasikan sebuah gambar, bahkan dapat membawa kenikmatan menonton bioskop di rumah. Dengan teknologi HDTV, kini konsumen dapat lebih menikmati gambar yang sangat detail untuk dinikmati bersama keluarga. Artikel ini berdasarkan studi literatur, yang bersumber dari pencarian referensi cetak dan elektronik. Semakin tinggi resolusi tidak selalu berarti tampilan gambar akan menjadi lebih baik. Untuk format HD tersedia 720 garis vertical, sementara untuk full HD ada 1080 garis vertikal. TV dengan resolusi rendah mungkin saja memiliki kualitas gambar bagus, tapi tidak semua kemewahan bisa dinikmati secara detil seperti yang dihasilkan format HD atau Full HD.
\end{abstract}

Kata kunci: televisi, monitor, HDTV, resolusi 


\section{PENDAHULUAN}

Dalam kehidupan sehari-hari, setiap manusia sebagai mahluk sosial harus selalu berkomunikasi dan mengetahui lingkungan di sekitarnya. Di masa yang sudah sangat pesat kemajuan teknologi nya, kini manusia sudah biasa mengupdate informasi dengan berbagai media, seperti radio, televisi, telepon maupun internet. Salah satu sarana untuk meng update informasi yang sudah lama kita jumpai, yaitu televisi. Sudah lebih dari lima puluh tahun lamanya, televisi menemani kita sebagai jendela informasi yang menyampaikan kabar di dunia ini.

Televisi yang sehari hari kita lihat di ruang keluarga bukan lah hanya sekedar teknologi biasa layaknya sebuah alat pemanggang roti. Televisi berfungsi sebagai "jendela dunia” yang menceritakan banyak pengalaman diluar kehidupan kita sehari hari. Sebagai alat penghantar kabar dunia kepada kita, televisi juga merupakan media hiburan serta sebagai media penyalur budaya.

Dalam perkembangannya, selama dua puluh tahun terakhir, televisi bukan hanya sebagai jendela informasi dunia, tetapi sudah merambah kepada perkembangan teknologi sebagai media hiburan dirumah dimana televisi konvensional, yang menggunakan tabung dengan menampilkan gambar yang cukup baik, kini berkembang menjadi televisi layar datar yang mempunyai kualitas gambar yang sangat jernih dan detail serta layar yang lebih luas layaknya seperti saat kita menikmati film di bioskop.

\section{METODE}

Artikel ini berdasarkan studi literatur, yang bersumber dari pencarian referensi cetak dan elektronik.

\section{HASIL DAN PEMBAHASAN}

Sebagai penunjang media hiburan di rumah, televisi, kini mengalami kemajuan yang sangat pesat, diikuti dengan tekhnologi digital yang sangat mempengaruhi kualitas sebuah televisi untuk mempresentasikan gambar dan film dengan kualitas yang sangat baik. Berbicara mengenai TV Digital, dapat diasumsikan dengan banyak kemungkinan. yang dimana bisa berupa HDTV (High Definition TV). HDTV bisa melibatkan beberapa fakor seperti banyaknya sebuah garis dalam sebuah layar, layar lebar seperti di bioskop, serta sken gambar yang bisa mengurangi gangguan pada gambar.

HDTV adalah sebuah sistem televisi digital yang menawarkan kualitas gambar yang lebih baik dibandingkan dengan sistem TV konvensional yang masi mengunakan system tabung. HDTV bisa menghasilkan semua faktor menjadi lebih baik, transmisi gambar yang lebih rinci, gambar yang lebih luas (perbandingan gambar16:9) dan suara stereo sampai dengan enam titik, yang memungkinkan untuk menggunakan pilihan beberapa bahasa, dan menu pilihan lainnya.

Saat ini tidak sulit menemukan HDTV di pasaran, banyak sekali produsen yang berlomba menjual produknya, dengan menawarkan segala kelebihan produk HDTV masing-masing, dari kualitas gambar dan warna, suara sampai dengan tehnologi baru seperti layar full HDTV yang dapat menayangkan film dalam bentuk 3D lengkap dengan kacamata 3D-nya. Di pasaran, HDTV ini banyak di tawarkan dari beberap jenis tehknologi layar datar seperti Plasma TV, LCD TV sampai dengan LED TV yang dipercaya lebih hemat energi. Jenis layar datar ini, selain digunakan untuk layar 
televisi, juga di gunakan untuk kepeluan monitor yang biasa di gunakan untuk para pengguna komputer, walau pun berbeda fungsi tidak menutup kemungkinan untuk konsumen menggunakan HDTV untuk dipasangkan dengan komputer mereka sebagai layar monitor.

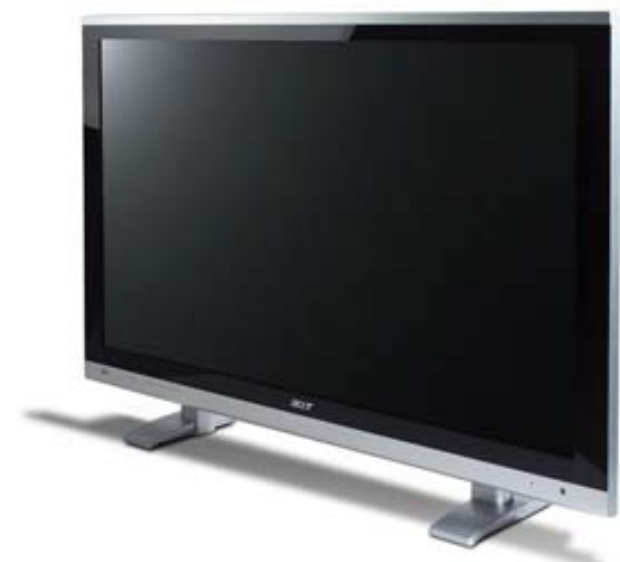

Gambar 1 Plasma TV

\section{Plasma TV}

Plasma TV adalah salah satu TV layar datar yang ditawarkan, Jenis tv ini mampu menampilkan layar tv dalam skala yang besar. Teknologi layar datar ini menggunakan bahan dasar gas. Dengan ukuran umur lampu sekitar 60.000 jam, dimana dalam pemakaian sehari hari berarti bisa di pakai bertahun tahun lamanya.

\section{LCD TV dan LED TV}

Pada dasarnya, teknologi Layar LCD dan LED monitor menggunakan dasar teknologi yang sama untuk menampilkan gambar, namun berbeda dalam jenis lampu yang digunakan. Pada layar LCD, menggunakan lampu neon katoda dingin untuk penerangnya, sedangkan pada layar LED menggunakan dioda yang memancarkan cahaya. Ini adalah perbedaan utama antara kedua teknologi ini. Jadi, sebetulnya layar LED adalah jenis dari layar LCD. Namun layar LED mampu menciptakan kualitas gambar yang lebih baik dan lebih nyaman di mata daripada LCD. Dan juga yang tidak kalah penting adalah layar LED ini lebih hemat energi.
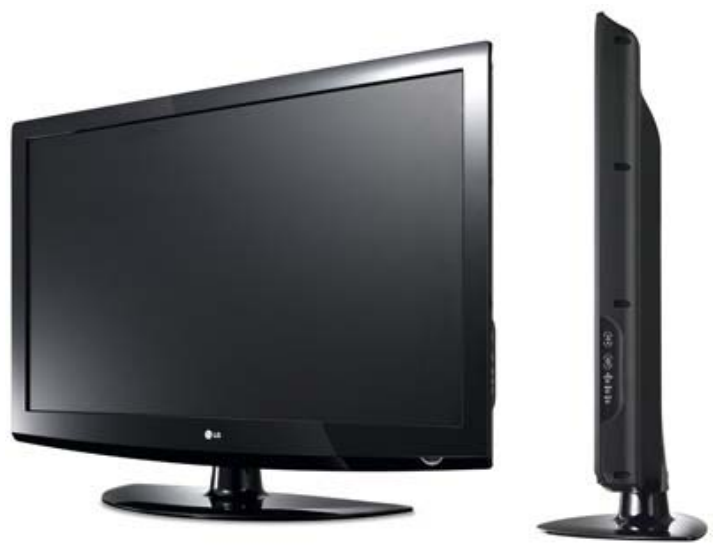

Gambar 2 LCD TV 

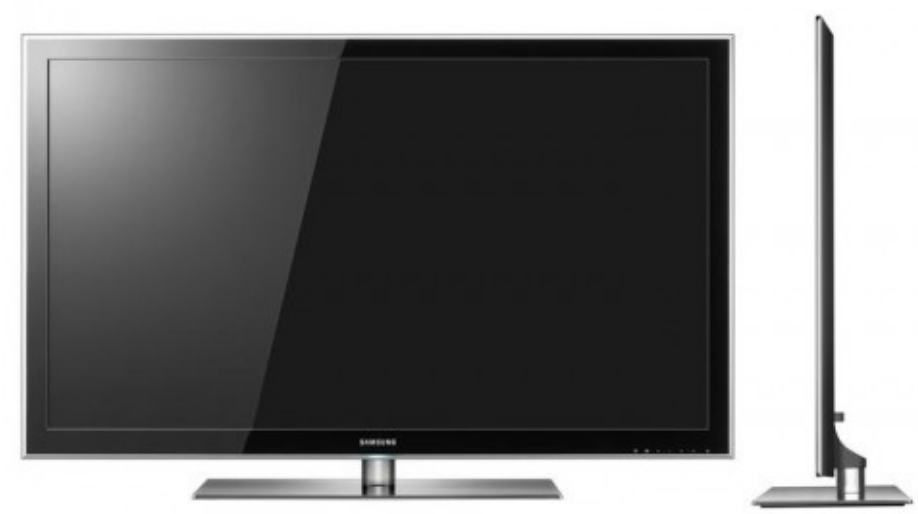

Gambar 3 LED TV

Dengan segala kelebihannya, banyak sekali pengguna komputer memilih layar LED sebagai monitor, karena tetap nyaman untuk mata bila harus berlama-lama di depan komputer. Tetapi ada satu kelemahan dari teknologi LED. Dalam proses produksinya, pembuatan perangkat ini jauh lebih mahal dibanding dengan produksi layar LCD, sehingga para konsumen harus mengeluarkan uang yang lebih banyak untuk mendapatkan kenyamanana dan kepuasan yang ditawarkan LED.

Dari ketiga jenis di atas, persamaan yang mereka tawarkan adalah sama sama menawarkan tv layar lebar (16:9) dan resolusi yang tinggi hingga bisa menghasilkan gambar yang jauh lebih baik di banding dengan tv konvensional dengan teknologi yang masih menggunakan layar tabung (4:3). Resolusi yang di tawarkan juga bervariasi seperti HD Ready dengan menggunakan resolusi 1360x768 piksel sampai dengan Full HD dengan menampilkan resolusi 1920x1080 piksel.

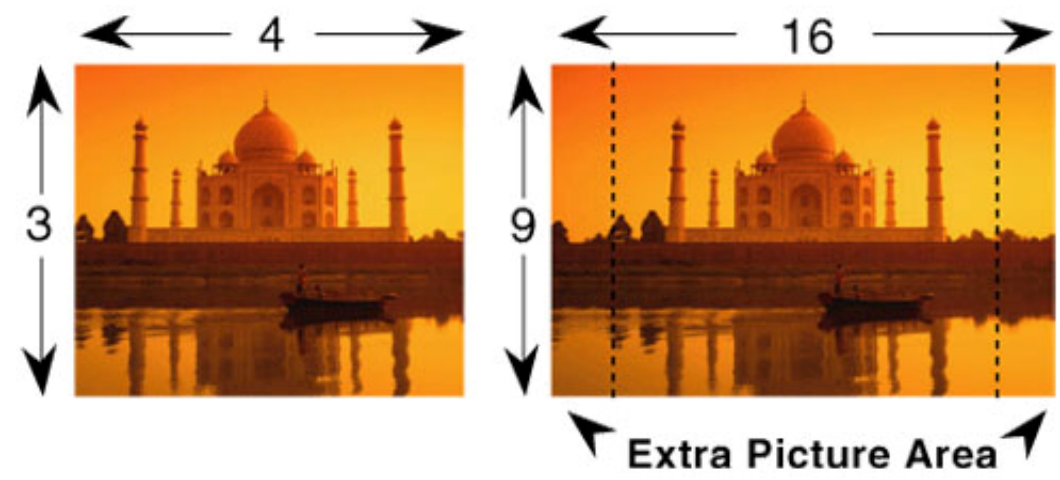

Gambar 4 Perbandingan Aspek Rasio 4:3 dan 16:9

Aspek rasio yang umum digunakan untuk penyajian film di bioskop adalah perbandingan 01,85:1 dan 2.39:1 perbandingan yang paling tepat antara televisi konvensional dan HDTV, tapi bagaimana pun juga, sebuah film yang baik tidak didasari pada aspek rasio saja, namun dengan kualitas gambar yang detail dan format HDTV memungkinkan untuk melihat gambar dari sudut yang lebih luas.

Saat ini sistem HDTV yang paling populer adalah: (1) sistem dengan 750 garis/gambar, 60 gambar/detik, progressive scanning 60 bidang/detik (non-interlaced) dan 720 baris aktif per gambar; (2) sistem dengan 1125 garis/gambar, 30 gambar/detik dan alternated scanning 60 bidang/garis aktif detik dan 1080 per gambar. 

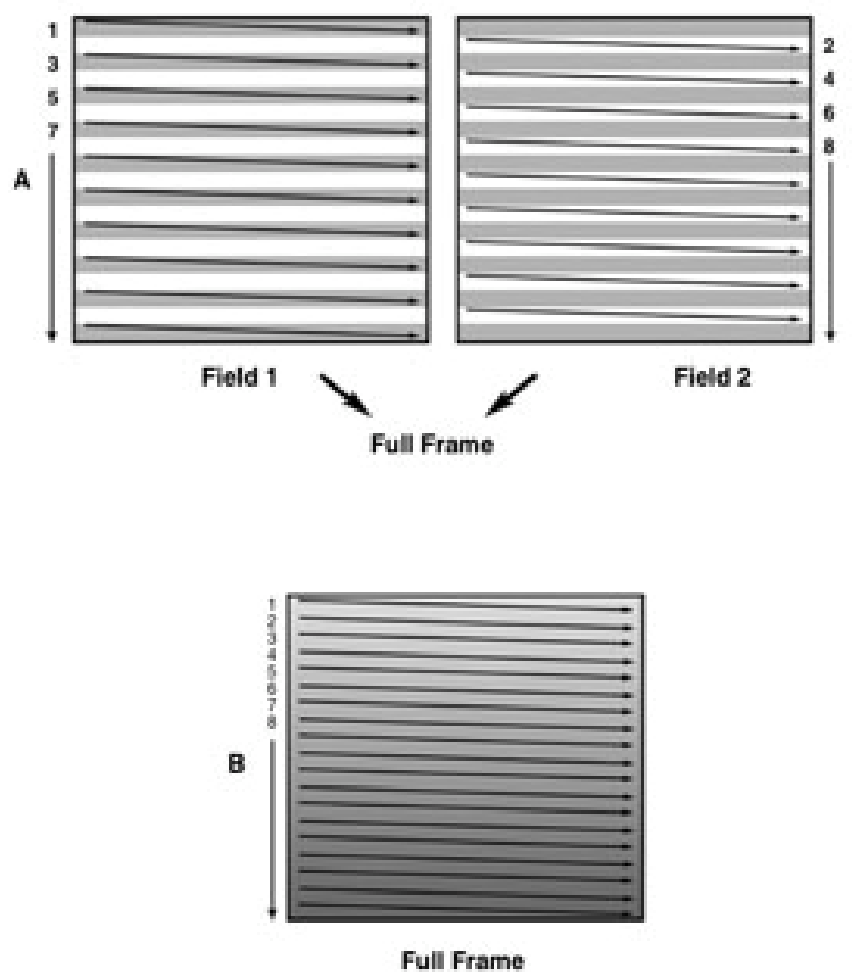

Gambar 5A Interlace Scanning; 5B Progressive Scanning Sumber: How Video Works, 2004

Interlace scanning adalah proses pemisahan suatu frame video ke dalam dua bidang. Salah satu bidang yang berisi informasi baris video sementara yang lain bahkan berisi garis yang membentuk gambar. Dimana saat dimainkan kembali, dua bidang yang dijalin bersama untuk membentuk satu frame yang lengkap dari sebuah video. Progressive scanning adalah cara menampilkan, menyimpan atau mentransmisikan gambar bergerak di mana semua baris dari setiap frame digambar secara berurutan. Hal ini berbeda dengan interlace yang digunakan dalam sistem televisi konvensional di mana hanya garis ganjil, maka baris bahkan setiap frame (setiap gambar yang sekarang disebut field) diambil bergantian.

Sinyal HDTV ditampilkan pada format 720p atau 1080i, dimana 720p berarti ada 720 garis horizontal progresif scan, dan 1080i menunjukkan bahwa ada garis horizontal 1080 interlace. Terlepas dari kenyataan bahwa ada perbedaan yang signifikan antara jumlah garis horizontal scan, gambar yang diperoleh dengan 720p dan 1080i boleh dikatakan sangat mirip.

\section{Perbedaan antara HDTV dan HD Monitor}

Sering kali terdengar pertanyaan seperti apa perbedaan antara HD monitor dan HDTV. Ada tiga perbedaan yang utama, yaitu resolusi, jenis koneksi, dan juga tuner. Sebuah TV dapat dikatakan sebagai HDTV bila unit ini memiliki tuner, yang memungkinkan sebuah TV dapat menangkap siaran TV, pada dasarnya seperti NTSC dan PAL.

Mungkin saja pada awal nya monitor yang masih menggunakan teknologi konvensional yang dikenal sebagai CRT atau masih menggunakan tabung, dimana sewaktu membaca tulisan atau teks bisa sangat menyakitkan mata karena masih menggunakan system tabung interlace, tapi itu dapat diatasi dengan adanya koneksi yang berbentuk VGA dengan tampilan progresif. Tapi mada masa 
sekarang, dimana monitor juga sudah menggunakan layar datar, layar standar dengan 4:3 ataupun layar lebar dengan perbandingan 16:9. Sudah menggunakan system progresif scan, dimana bila membaca sebuah text atau tulisan di jarak yang dekat tidak akan membuat mata menjadi sakit. Kini layar monitor juga sudah memiliki resolusi yang sangat tinggi yaitu resolusi Full HD, 1920X1080 piksel dengan progresif scan.

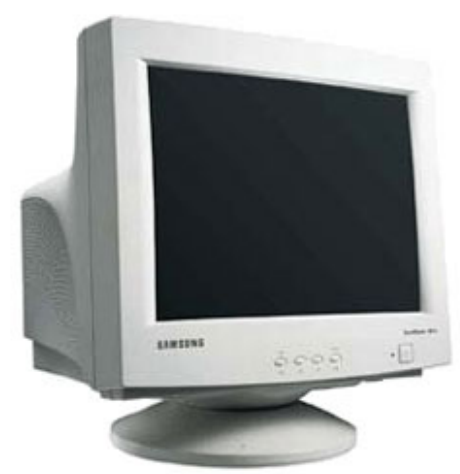

Gambar 6 Monitor CRT

Kini, monitor pun juga sudah merambah ke pasar dengan menawarkan kemewahan layaknya yang ditawarkan oleh HDTV, dimana memiliki resolusi yang tinggi yang menujang tampilan gambar yang dihasilkan sangat luar biasa, baik detail dan warna. Dan beberapa produsen monitor pun juga sudah menawarkan monitor dengan dua fungsi yaitu moitor dan tv, dmana mereka sudah menanamkan tv tuner didalamnya yang memungkinkan untuk digunakan sebagai tv. Walaupun koneksi yang di tawarkan monitor sangat minim di banding dengan HDTV yang menawarkan banyak tingkat konektifitas untuk mendukung gambar yang bisa di hasilkan seperti composite (RCA), VGA (monitor), component, dan juga HDMI.

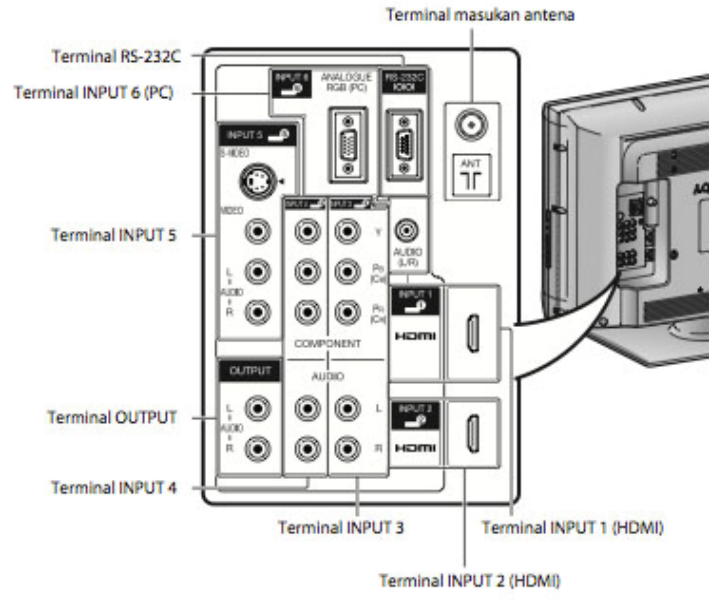

Gambar 7 Panel koneksi pada HDTV

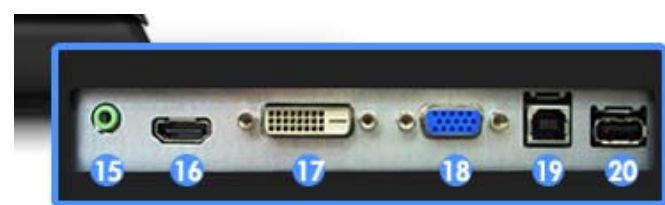

Gambar 8 Panel koneksi pada HD Monitor (Jack Audio, HDMI, DVI-D, VGA dan USB port)

Monitor juga mendukung suara dengan internal speaker (Gambar 8). Pada umumnya, monitor hanya menawarkan koneksi seperti VGA, DVI dan juga HDMI. Namun itu cukup utuk menampilkan gambar yang sangat baik pada resolusi yang sangat tinggi. Untuk besar monitor pun juga sangat bervariatif, mulai dari 15 inch sampai dengan ukuran besar yaitu 30 inch. 

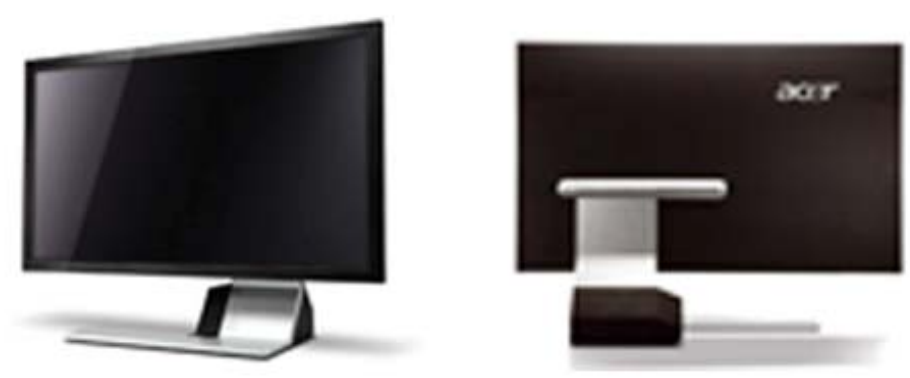

Gambar 9 LCD monitor

Lain lagi halnya dengan monitor yang diproduksi oleh Apple, yaitu LED Cinema Display, di mana monitor ini menggunakan layar LED yang kini sudah banyak merambah di banyak tipe monitor. Monitor ini didesain secara spesifik untuk laptop kelauran Apple sendiri. Banyak sekali fitur yang di tawarkan dari monitor ini, dengan ukuran monitor 24 inch dan 27 inch, dengan tingkat kecerahan320 nits, memiliki contras ratio 1000:1 dan sudut pandang 178 derajat, serta respon time 14ms (semakin kecil respon time, semakin halus gerakan yang dihasilkan pada sebuah film). Layar ini juga memiliki kamera iSight built-in dan mikrofon serta speaker 2.1 stereo yang ditanam di bagian bawah serta satu speaker di bagian belakang. Tapi ada sedikit kekurangan yaitu konektor Mini Display Port, yang di dasari oleh teknologi Display port. Monitor ini hanya bisa di gunakan oleh perangkat/laptop Apple yang baru. Namun, monitor ini cukup terang dan ramah lingkungan (Galbraith, 2009).

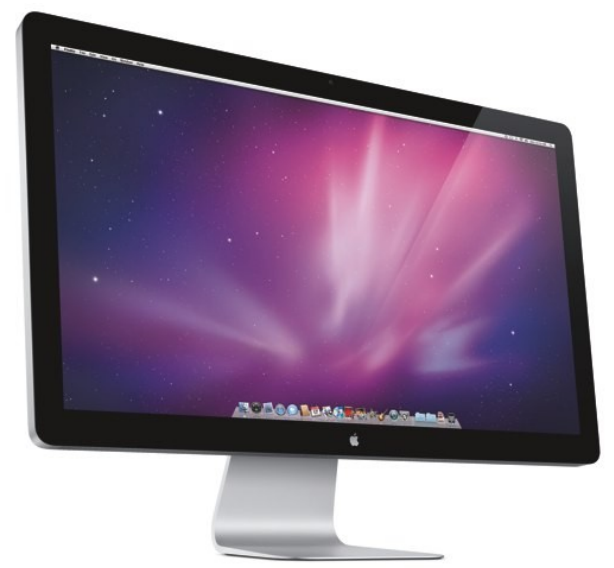

Gambar 10 LED Cinema Display

\section{PENUTUP}

Seberapa pentingkah memiliki sebuah teknologi HDTV, semua kembali kepada kebutuhannya. Patut di pertimbangkan juga, bila kita masih menyaksikan siaran tv local dimana, stasiun tv di Indonesia masih menggunakan system analog, dimana bila di saksikan menggunakan HDTV, maka akan menghasilkan gambar yang sedikit mengganggu. Walaupun sudah ada stasiun tv yang beralih ke system digital, tapi untuk kualitas gambar, masih bisa diterima dengan baik dengan tekhnologi televisi konvensional yang masih menggunakan tabung. Tetapi bila digunakan untuk menunjang menikmati film atau untuk mendukung perangkat console game dengan mengharapkan kualitas gambar yang sangat baik, tepat untuk memilih hdtv sebagai perangkat hiburan. Walaupun 
harus ditunjang dengan perangkat yang lain seperti Blue-Ray player sudah dapat menyajikan konten dengan definisi yang tinggi. Serta perangkat audio yang menunjan 5.1 titik. Lalu pemilihan resolusi juga sebagai salah satu yang patut diperhitungkan adalah apakah menjatuhkan pilihan pada HD ready dengan besar pixel 1366x768 atau dengan Full HD dengan 1920x1080 pixel. Kembali lagi sejauh mana ingin menikmati sebuah hiburan yang memanjakan mata. Semakin tinggi resolusi tidak selalu berarti tampilan gambar akan menjadi lebih baik. Tapi untuk format high-def dan full HD, Sebuah TV memerlukan resolusi minimum untuk mendisplaykan semua informasi yang tersimpan dalam sinyal. Untuk format HD tersedia 720 garis vertical, sementara untuk full HD ada 1080 garis vertikal. TV dengan resolusi rendah mungkin saja memiliki kualitas gambar bagus, tapi tidak semua kemewahan bisa dinikmati secara detil seperti yang dihasilkan format HD atau Full HD (Instant Expert, 2007).

\section{DAFTAR PUSTAKA}

Galbraith, J. (Maret, 2009). Laptop companion. Macworld, p. 40.

Instant Expert. (Juni, 2007). What HiFi,p. 66. 